\title{
ANALISIS FAKTOR-FAKTOR PENYEBAB KETERLAMBATAN WAKTU PADA PEKERJAAN BASEMENT GEDUNG BERTINGKAT SEMI TOP-DOWN
}

\author{
Joshua Wangsadiputra ${ }^{1}$ dan Jane Sekarsari ${ }^{2}$ \\ ${ }^{1}$ Program Studi Sarjana Teknik Sipil, Universitas Tarumanagara, Jl. Letjen S. Parman No.1 Jakarta \\ joshua.325160062@stu.untar.ac.id \\ ${ }^{2}$ Program Studi Sarjana Teknik Sipil, Universitas Tarumanagara, Jl. Letjen S. Parman No.1 Jakarta \\ tamtana.js@gmail.com
}

Masuk: 18-07-2020, revisi: 11-08-2020, diterima untuk diterbitkan: 02-11-2020

\begin{abstract}
Time delays in construction project will be very detrimental for both the provider and user of construction service because it can cause a conflict which leads to time demand and additional cost. The timeliness in construction of basement is one of the important aspect to gain a success at construction project, remembering basement is an early phase of development at high-rise building project. The purpose of this study is to analyze the factors that can cause time delay in high-rise building semi top-down basement work. The research method used in this study is quantitative and descriptive approach with questionnaire distribution to some high-rise building projects with semi top-down basement. With the help of SPSS software, next step is to analyzing the data in the form of a validity test, reliability test, normality test, and Relative Importance Index (RII) test. The result of this study shows 5 factors that cause the most influence the delay of semi top-down basement work based on the importance ranking is variation and changes of order by owner, low productivity level of labors, leak on the diaphragm wall, repeated changes rebar layout due to space that too narrow, and material delivery delays.
\end{abstract}

Keywords: time delay; basement; semi top-down.

\begin{abstract}
ABSTRAK
Keterlambatan waktu pada pelaksanaan proyek akan sangat merugikan para pelaku jasa konstruksi karena dapat menyebabkan konflik yang berujung terjadinya tuntutan waktu dan biaya tambahan. Ketepatan waktu pada pekerjaan basement merupakan salah satu aspek penting dalam kelancaran suatu proyek konstruksi, mengingat basement merupakan salah satu pembangunan tahap awal pada proyek gedung bertingkat. Penelitian ini bertujuan untuk menganalisa faktor-faktor yang dapat mempengaruhi keterlambatan waktu pada pekerjaan basement semitop down. Metode penelitian yang digunakan pada studi ini adalah pendekatan secara deskriptif kuantitatif dengan penyebaran kuesioner kepada beberapa proyek gedung bertingkat dengan basement semi top-down. Selanjutnya, dilakukan pengolahan data dengan bantuan software SPSS berupa uji validitas, uji reliabilitas, uji normalitas, dan Relative Importance Index (RII). Hasil penelitian menunjukkan, terdapat 5 faktor yang paling mempengaruhi keterlambatan pekerjaan basement semi top-down menurut tingkat pengaruhnya yaitu perubahan perintah kerja dan variasi dari owner, produktivitas pekerja lapangan yang rendah, terjadi kebocoran pada Dinding Penahan Tanah (DPT), pengaturan tata letak penyimpanan tulangan yang berulang-ulang akibat lahan yang terlalu sempit, dan pengiriman material yang terlambat.
\end{abstract}

Kata kunci: keterlambatan waktu; basement; semi top-down.

\section{PENDAHULUAN}

Perkembangan konstruksi di Jakarta menyebabkan lahan pembangunan yang semakin berkurang. Banyak gedunggedung yang membangun secara vertikal dan menghindari pembangunan secara horizontal. Gedung-gedung tidak hanya berlomba untuk menjulang keatas tetapi juga menjulang kebawah atau dapat disebut dengan konstruksi basement. Pekerjaan basement merupakan salah satu pekerjaan yang penting dalam suatu konstruksi bangunan gedung bertingkat, mengingat basement merupakan pembangunan tahap pertama yang sangat berpengaruh terhadap durasi proyek tersebut.

Menurut Praboyo (1999) keterlambatan pelaksaan proyek umumnya selalu menimbulkan akibat yang merugikan bagi kedua belah pihak, karena dampak keterlambatan adalah konflik yang terjadi dan perdebatan tentang hal yang menjadi penyebab, juga tuntutan waktu, dan biaya tambahan. 
Terdapat beberapa faktor yang bisa menjadi permasalahan dan menyebabkan keterlambatan. Menurut Kog (2019), ada beberapa tantangan utama pada sektor konstruksi di Indonesia, salah satunya adalah ketersediaan material, dan sumber daya manusia. Meskipun Indonesia mempunyai beberapa pekerja muda, mencari pekerja insinyur yang memenuhi syarat dan berkompeten tidaklah mudah.

Melihat latar belakang dan identifikasi masalah tersebut, rumusan masalah pada penelitian ini adalah sebagai berikut:

1. Faktor-faktor apa saja yang menyebabkan keterlambatan waktu pada pekerjaan basement proyek konstruksi gedung bertingkat yang menggunakan metode semi top-down?

2. Faktor apakah yang paling berpengaruh terhadap keterlambatan waktu pada pekerjaan basement proyek konstruksi gedung bertingkat yang menggunakan metode semi top-down?

Melihat latar belakang, identifikasi masalah, dan rumusan masalah tersebut, tujuan dari penelitian ini adalah sebagai berikut:

1. Mendapatkan faktor-faktor penyebab keterlambatan waktu pada pekerjaan basement proyek konstruksi gedung bertingkat yang menggunakan metode semi top-down.

2. Mendapatkan faktor yang paling berpengaruh terhadap keterlambatan waktu pada pekerjaan basement proyek konstruksi gedung bertingkat yang menggunakan metode semi top-down.

Konstruksi dapat diartikan sebagai susunan dari berbagai elemen suatu bangunan yang memiliki kedudukan setiap bagian-bagiannya sesuai dengan fungsinya (Rani, 2016). Secara umum, terdapat dua macam konstruksi, yaitu konstruksi bangunan gedung yang mencangkup bangunan gedung, perumahan, dan lain-lain. Terdapat juga konstruksi bangunan sipil, seperti jalan raya, jembatan, bendungan, dan lain-lain.

Menurut Rani (2016), dikenal juga empat tipe konstruksi, yaitu:

- Konstruksi pemukiman

Termaksud dalam konstruksi ini adalah: rumah tinggal, hunian, dan komplek pemukiman. Penataan yang baik diperlukan pada konstruksi ini dengan memperhatikan perkembangan untuk masa-masa yang akan dating.

- Konstruksi gedung

Termaksud dalam konstruksi ini adalah: gedung pemerintahan, gedung sekolah, gedung perkantoran, gedung perbankan, dan lain-lain. Penataan yang perlu diperhatikan pada umumnya adalah penataan fasilitas, penataan keamanan, dan lain-lain.

- Konstruksi rekayasa berat

Pada konstruksi ini, banyak alat-alat berat sehingga memerlukan penataan alat-alat berat tersebut agar alatalat berat tersebut tidak terbengkalai di lokasi konstruksi.

- Konstruksi Industri

Termaksud dalam konstruksi ini adalah: kawasan industri, pabrik, dan lain-lain. Penataan yang diperlukan adalah penataan terhadap pengaruh limbah yang ditimbulkan terhadap lingkungan.

\section{Pengertian proyek konstruksi}

Proyek konstruksi merupakan suatu kegiatan yang saling berhubungan untuk mendapatkan hasil suatu infrastruktur atau konstruksi. Proyek konstruksi bersifat sangat unik dan tidak mungkin berjalan sama persis dua kali karena proyek konstruksi memerlukan keahlian atau skills yang berbeda-beda pada tiap pelaksanaannya.

Ketika berjalannya suatu proyek konstruksi, Kerzner (2003) menyatakan bahwa terdapat tiga hal utama yang perlu diperhatikan pada proyek konstruksi yaitu mutu, biaya dan waktu. Biasanya pada suatu proyek konstruksi mutu adalah hal yang diutamakan agar sesuai dengan rencana. Namun tidak selamanya suatu proyek dapat berjalan lancar, bisa saja terjadi keterlambatan dan pembengkakan biaya yang memengaruhi waktu dan biaya.

\section{Tahapan proyek konstruksi}

Menurut (Teulah, et al., 2014), berikut merupakan proses atau tahapan dalam pelaksanaan proyek konstruksi:

1. Tahap Perencanaan

Pada setiap proyek konstruksi selalu dimulai dengan rencana atau gagasan. Tahap perencanaan haruslah dipikirkan secara matang-matang dan memiliki tujuan yang jelas agar proses dapat berjalan dengan baik. Berbagai kegiatan yang dilakukan pada tahap ini adalah:

- Menyusun tenaga kerja yang dibutuhkan;

- Menentukan anggaran dan durasi secara kasar;

- Menentukan alokasi biaya penggunaan biaya; 
2. Tahap Perancangan

Pada tahap ini perancangan dilakukan untuk mendapatkan detail-detail yang sesuai dengan keinginan dari owner. Pada tahapan ini pihak yang lebih terlibat ialah pihak konsultan, dapat berupa konsultan perencana struktur, konsultan MK, dan quantity surveyor. Kegiatan yang dilakukan pada tahap ini adalah:

- Merancang desain struktur yang lebih mendetail;

- Menentukan tata letak;

- Mengestimasikan Rencana Anggaran Biaya (RAB) dan Bill of Quantity (BOQ);

- Memperkirakan jadwal durasi proyek;

3. Tahap Pelelangan

Pada tahap ini akan ditentukan kontraktor sebagai pelaksana dan atau disertakan beberapa sub-kontraktor yang akan melaksanakan pekerjaan pelaksanaan proyek di lapangan.

4. Tahap Pelaksanaan

Tahapan ini merupakan tahapan dimana dilaksanakan pekerjaan untuk mewujudkan sasaran akhir proyek yang telah direncakan diawal.

5. Tahap Pemeliharaan

Tahapan ini memiliki tujuan untuk menjamin agar konstruksi bangunan yang telah selesai sesuai dengan kontrak yang disetujui dan segala fasilitas yang ada dapat berjalan dengan baik.

\section{Pengertian basement}

Semakin berkurangnya lahan pembangunan konstruksi dan semakin padatnya pembangunan di Indonesia, menekan gedung-gedung bertingkat untuk miliki perluasan secara vertikal. Gedung-gedung berlomba untuk menjadi sang pencakar langit dan semakin menggali kedalam tanah untuk memiliki basement yang lebih dalam dan memadai. Basement atau rubanah memiliki fungsi sebagai lahan parkir.

Basement merupakan lapisan vertikal dari bangunan yang menjulang ke bawah lapisan permukaan tanah bangunan tersebut. Dengan berkurangnya lahan pembangunan secara horizontal, basement dapat menjadi solusi untuk lahan parkir dan utilitas suatu bangunan (Lafiza, 2017).

\section{Metode konstruksi basement top-down}

Metode top-down merupakan metode dimana pekerjaan struktur basement dapat dimulai bertahap dari lantai dasar (ground) hingga elevasi paling dalam yang telah direncanakan. Selama jalannya konstruksi, terdapat king post yang merupakan bagian dari tiang pondasi dan berfungsi sebagai penyokong struktur sementara yang nantinya akan dicor dan menjadi kolom secara permanen (Prawidiawati, 2015).

Saat proses penggalian, biasanya digali suatu lubang (void) yang nantinya akan menjadi akses excavator untuk dapat menggali tanah. Setelah semua pekerjaan konstruksi selesai, king post akan dicor dan akan menjadi struktur permanen berupa kolom pada lantai basement. Lubang yang digunakan sebagai akses excavator pun akan ditutup dan dicor kembali manjadi pelat lantai. Tata letak diaphragm wall dan proses penggalian tanah dengan metode top-down dapat dilihat pada gambar 1 dan gambar 2. Berikut merupakan garis besar proses pekerjaan basement dengan metode top-down (Sari, 2015):

1. Pekerjaan dinding penahan tanah (diaphragm wall);

2. Pekerjaan bored pile bersamaan dengan king post;

3. Pekerjaan basement satu yang dicor diatas permukaan tanah lantai kerja;

4. Penggalian tanah untuk basement lantai selanjutnya melalui void sementara menggunakan excavator kecil;

5. Pekerjaan struktur basement dua, dan dilanjutkan penggalian tanah lantai seterusnya;

6. Pekerjaan diulang sampai menuju lantai basement paling bawah;

7. Pengecoran raft foundation;

8. King post dicor dan menjadi kolom permanen, void juga kembali dicor.

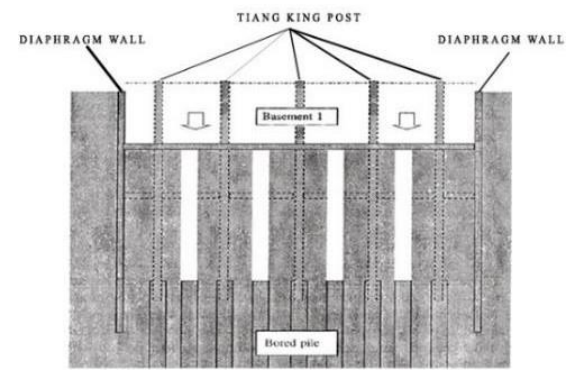

Gambar 1. Tata letak diaphragm wall dan king post (Sumber: Tanubrata, 2015) 


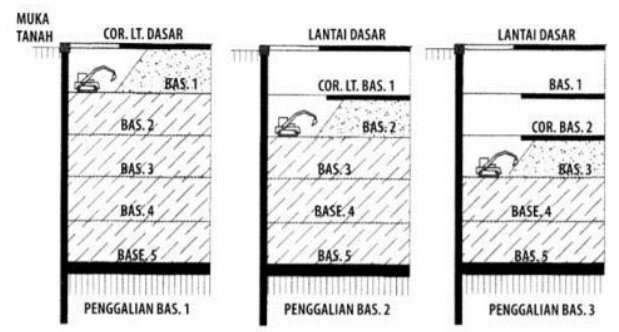

Gambar 2. Proses penggalian tanah dengan metode top-down (Sumber: Mistra, 2012)

\section{Metode konstruksi semi top-down}

Dalam metode pekerjaan gedung bertingkat, selain terdapat pekerjaan dengan metode top-down terdapat juga pekerjaan yang serupa namun sedikit berbeda, yaitu pekerjaan semi top-down. dapat dikatakan pula bahwa, metode pekerjaan semi top-down seperti penggabungan antara metode pekerjaan top-down dan bottom-up.

Pekerjaan top-down mengerjakan tingkat basement dan lantai diatasnya secara bersamaan, sementara pada pekerjaan semi top-down, dengan metode yang sama dengan top-down namun diselesaikan pekerjaan basement terlebih dahulu dan setelah semua pekerjaan basement telah selesai akan dilanjutkan dengan pekerjaan struktur atas.

\section{Keterlambatan proyek konstruksi}

Dalam suatu proyek konstruksi, keterlambatan dapat diartikan sebagai suatu pekerjaan yang selesai melebihi durasi pada kontrak maupun durasi yang telah disetujui. Dalam kedua kasus tersebut, keterlambatan proyek biasanya menyebabkan hal-hal yang sangat merugikan (Lo, et al., 2006).

Keterlambatan proyek dapat menjadi sumber utama pada pembengkakan biaya proyek. Keterlambatan juga dapat menyebabkan sumber terjadinya perselisihan antar kedua pihak pelaku jasa konstruksi yaitu pemilik dan kontraktor. Kontraktor dapat terkena biaya overhead atau biaya tambahan, dan pemilik dapat terkena pengurangan pemasukan proyek akibat terlantarnya penggunaan fasilitas (Alifen, et al., 2000).

\section{Dampak keterlambatan pada proyek konstruksi}

Keterlambatan proyek konstruksi dapat menyebabkan kerugian bagi banyak pihak, terutama bagi pihak pelaku jasa konstruksi. Menurut Widhiawati (2009) dalam Wisudanto (2012), berikut beberapa dampak dari keterlambatan proyek konstruksi bagi kontraktor, konsultan, dan owner:

1. Kontraktor:

Diakibatkan penyelesaian proyek yang terlambat, timbul biaya tambahan yang lebih besar akibat keterlambatan tersebut. Semakin lama durasi penyelesaian proyek, maka biaya overhead yang merupakan biaya perusahaan secara keseluruhan akan semakin membengkak.

2. Konsultan:

Penyelesaian proyek konstruksi yang terlambat akan menyebabkan kerugian waktu bagi konsultan. Konsultan akan semakin lama menyelesaiakan proyek tersebut dan akan terhambat untuk mengerjakan proyek konstruksi selanjutnya.

3. Owner:

Proyek konstruksi yang terlambat akan merugikan owner dalam aspek pendapatan atau penghasilan Jika owner merupakan pihak swasta, seperti keterlambatan pada konstruksi restoran, maka akan merugikan pendapatan owner yang seharusnya restoran tersebut beroperasi pada jadwal yang telah direncanakan.

\section{Faktor-faktor keterlambatan pada proyek konstruksi}

Terdapat beberapa faktor yang dapat menyebabkan keterlambatan pada proyek konstruksi. Pada penelitian Kog (2019), terdapat beberapa faktor yang memengaruhi keterlambatan pada proyek konstruksi di Indonesia, Malaysia, Thailand dan Vietnam. Beberapa faktor tersebut adalah:

1. Perubahan perintah oleh owner selama konstruksi berlangsung;

2. Pengiriman material konstruksi yang terlambat;

3. Kurang lengkapnya ketersediaan alat dan bahan;

4. Penjadwalan yag kurang baik oleh kontraktor;

5. Pekerja lapangan yang tidak memiliki ahli; 
6. Kontraktor yang kurang kompeten;

7. Manajemen lapangan dan pengawasan pekerjaan yang buruk;

8. Pekerjaan ulang akibat kesalahan pada konstruksi;

9. Gambar kerja yang kurang jelas.

Sementara pada penelitian (Lo, et al., 2006), faktor-faktor penyebab keterlambatan pada proyek konstruksi di Hong Kong adalah:

1. Owner Related:

- Perubahan dan variasi owner;

- Durasi kontrak dari owner yang kurang realistis;

2. Engineer Related:

- Persyaratan dan keinginan owner yang kurang realistis.

- Keterlambatan dalam menyediakan informasi gambar kerja;

- Perubahan desain gambar;

- Lambatnya koordinasi dalam mencari persetujuan dari pihak otoritas.

3. Contractor Related:

- Kurangnya pengalaman kontraktor;

- Tenaga kerja yang tidak memiliki keahlian;

- Keterlambatan akibat sub-kontraktor;

- Keterlambatan akibat kecelakaan kerja.

4. Human Behaviour Related:

- Budaya pada daerah konstruksi yang memiliki kontroversi;

- Kurangnya komunikasi antar pekerja;

5. Project Related:

- Kurangnya komunikasi antar pelaku jasa konstruksi.

- Kondisi lahan proyek yang buruk;

- Kondisi tanah yang buruk;

- Lahan proyek yang terlalu sempit.

6. External Related:

- Kondisi lingkungan sekitar proyek yang kurang mendukung;

- Kondisi cuaca yang kurang mendukung.

Pada penelitian Tafazzoli \& Shrestha (2017), beberapa faktor yang menyebabkan keterlambatan pada industri konstruksi di Amerika Serikat adalah:

1. Contract Category:

- Penjadwalan yang kurang realistis;

- Kesalahan pada dokumen kontrak.

2. Owner Category:

- Perubahan perintah dari owner yang berlebihan;

- Pembayaran yang terlambat;

- Terlambat dalam menyetujui gambar kerja.

3. Contractor Category:

- Komunikasi yang buruk antara owner dengan kontraktor;

- Manajemen lapangan kontraktor yang buruk;

- Metode konstruksi yang kurang layak;

- Kurangnya efisiensi kontraktor (penyediaan material dan pekerja);

4. Designer Category:

- Kesalahan pada desain kerja;

- Keterlambatan pada penyediaan gambar kerja;

- Designer yang kurang berpengalaman.

Dalam penelitian (Wirabakti, et all., 2014) membahas beberapa faktor yang dapat menyebabkan keterlambatan pada proyek konstruksi bangunan gedung. Beberapa faktor terdapat dalam penelitiannya adalah:

1. Faktor tenaga kerja:

- Kurangnya motivasi para pekerja;

- Kurangnya keahlian tenaga kerja; 
- Kurangnya ketersediaan tenaga kerja;

- Pergantian tenaga kerja lama dengan baru;

2. Faktor bahan:

- Buruknya komunikasi antar pekerja lapangan dengan kontraktor.

- Keterlambatan pengiriman bahan;

- Ketersediaan bahan di pasaran;

- Kualitas bahan yang jelek;

- Perubahan material dari owner;

- Bahan mengalami kerusakan akibat terlalu lama disimpan.

3. Faktor karakteristik tempat:

- Keadaan permukaan dan bawah tanah;

- Keadaan bangunan disekitar proyek;

- Akses proyek yang sulit dicapai;

- Kebutuhan ruang kerja yang kurang.

4. Faktor Manajerial:

- Pengawasan proyek;

- Pengalaman manajer lapangan;

- Kesalahan manajemen material dan peralatan.

5. Faktor Peralatan:

- Ketersediaan peralatan;

- Kualitas peralatan yang buruk;

- Produktifitas peralatan.

6. Faktor Keuangan:

- Terlambatnya pembayaran pekerja;

7. Faktor Desain:

- Harga material yang terlalu mahal.

- Perubahan desain oleh owner

- Ketidaklengkapan informasi pada gambar kerja;

8. Faktor Lainnya:

- Desain yang terlalu rumit.

- Intensitas hujan;

- Banjir atau bencana alam yang tidak terduga;

- Kerusuhan.

\section{METODE PENELITIAN}

Pada metode penelitian ini akan dibahas proses penelitian yang akan dilaksanakan, variabel-variabel penelitian yang dipertimbangkan berdasarkan hasil studi pustaka dan studi lapangan, metode pengumpulan data, analisis dan pengolahan data tersebut.

Penelitian ini dilaksanakan dengan pengumpulan data melalui pembagian kuesioner pada studi kasus proyek konstruksi gedung bertingkat di DKI Jakarta yang menggunakan metode konstruksi semi top-down. Responden pengisian kuesioner akan dibataskan dengan kriteria sebagai berikut:

- Staff dan pegawai pada proyek konstruksi di lokasi studi kasus.

- Studi kasus dibatasi hanya berada di proyek konstruksi gedung bertingkat di Jakarta yang menggunakan metode konstruksi semi top-down.

- Jabatan/posisi pada pekerjaan yang ditinjau adalah staff site engineer, engineer, QS (Quantity Surveyor), dan QC (Quality Control).

- Pendidikan minimal adalah D3.

\section{Metode pengumpulan data}

Pada penelitian ini pengumpulan data bersifat kuantitatif. Data kuantitatif lebih bersifat konkret karena merupakan angka-angka. Data kuantitatif disini masih berupa data mentah yang nantinya perlu diolah agar menjadi lebih matang. Jenis data yang akan dikumpulkan pada penelitian ini adalah berupa data primer. Teknik pengumpulan dan pemberian skor pada penelitian ini menggunakan Teknik skala likert seperti yang terlihat pada Tabel 1 berikut. 
Tabel 1. Tabel skala likert

\begin{tabular}{ccc}
\hline Skala & & Keterangan \\
\cline { 1 - 1 } 5 & & Sangat Setuju \\
4 & & Setuju \\
3 & & Cukup Setuju \\
2 & & Tidak Setuju \\
1 & Sangat Tidak Setuju \\
\end{tabular}

(Sumber: Sugiyono, 2009)

\section{Penyusunan kuesioner}

Dari hasil studi pustaka dan juga hasil studi lapangan berupa wawancara dan pernyataan para ahli, didapatkan variabel-variabel yang akan diteliti yang dibagi menjadi 8 (delapan) kelompok besar yaitu faktor metode pelaksanaan, faktor material, faktor peralatan, faktor tenaga kerja, faktor manajerial, faktor terkait informasi, faktor karakteristik dan lingkungan proyek, dan faktor lainnya. Berdasarkan variabel-variabel didalam kelompok faktor yang diperoleh, maka penyusunan kuesioner dapat dilihat pada Tabel 2 sebagai berikut.

Tabel 2. Variabel pada kuesioner

\begin{tabular}{|c|c|}
\hline Simbol & Variabel Faktor-Faktor Keterlambatan pada Pekerjaan Basement \\
\hline & Kelompok: Faktor Metode Pelaksanaan \\
\hline $\mathrm{X} 1$ & Pekerjaan ulang akibat kesalahan pada penulangan struktur basement. \\
\hline $\mathrm{X} 2$ & Pekerjaan ulang yang disebabkan oleh kesalahan pelaksanaan konstruksi. \\
\hline \multirow[t]{2}{*}{$\mathrm{X} 3$} & Terjadi kebocoran pada Dinding Penahan Tanah (DPT). \\
\hline & Kelompok: Faktor Material \\
\hline $\mathrm{X} 4$ & Pengiriman material yang terlambat. \\
\hline X5 & Kualitas material yang kurang baik. \\
\hline X6 & Kerusakan pada material akibat terlalu lama disimpan. \\
\hline $\mathrm{X} 7$ & Ketersediaan material di pasaran. \\
\hline \multirow[t]{2}{*}{$\mathrm{X} 8$} & Keterlambatan pada fabrikasi material. \\
\hline & Kelompok : Faktor Peralatan \\
\hline X9 & Terbatasnya ketersediaan penyewaan alat yang khusus. \\
\hline \multirow[t]{2}{*}{$\mathrm{X} 10$} & Operator alat yang kurang handal. \\
\hline & Kelompok : Faktor Tenaga Kerja \\
\hline $\mathrm{X} 11$ & Kurangnya jumah tenaga kerja di lapangan. \\
\hline $\mathrm{X} 12$ & Produktivitas pekerja lapangan yang rendah. \\
\hline $\mathrm{X} 13$ & Perbedaan kulturasi pekerja. \\
\hline $\mathrm{X} 14$ & Pergantian tenaga kerja lama dengan yang baru. \\
\hline $\mathrm{X} 15$ & Pekerja yang terlalu lelah akibat jam lembur berlebihan. \\
\hline \multirow[t]{2}{*}{$\mathrm{X} 16$} & Motivasi pekerja yang rendah. \\
\hline & Kelompok : Faktor Manajerial \\
\hline $\mathrm{X} 17$ & Kurang efektifnya penjadwalan dari kontraktor. \\
\hline $\mathrm{X} 18$ & Perubahan perintah kerja dan variasi dari owner. \\
\hline X19 & Keterlambatan akibat sub-kontraktor. \\
\hline \multirow[t]{2}{*}{$\mathrm{X} 20$} & Persyaratan dan keinginan owner yang kurang realistis. \\
\hline & Kelompok : Faktor Terkait Informasi \\
\hline $\mathrm{X} 21$ & Kurangnya komunikasi antara kontraktor, owner, dan konsultan. \\
\hline $\mathrm{X} 22$ & Informasi pada gambar kerja yang kurang jelas. \\
\hline \multirow[t]{2}{*}{$\mathrm{X} 23$} & Keterlambatan dalam penyediaan gambar kerja. \\
\hline & Kelompok : Faktor Karakteristik dan Lingkungan Proyek \\
\hline $\mathrm{X} 24$ & Kondisi tanah pada proyek yang buruk. \\
\hline $\mathrm{X} 25$ & Kondisi bangunan sekitar proyek yang rusak atau terganggu. \\
\hline $\mathrm{X} 26$ & $\begin{array}{l}\text { Pengaturan tata letak penyimpanan tulangan yang } \\
\text { berulang-ulang akibat lahan yang terlalu sempit. }\end{array}$ \\
\hline \multirow[t]{2}{*}{$\mathrm{X} 27$} & Muka air tanah yang terlalu tinggi. \\
\hline & Kelompok : Faktor Lainnya \\
\hline $\mathrm{X} 28$ & Keadaan cuaca yang kurang mendukung. \\
\hline $\mathrm{X} 29$ & Banjir atau bencana alam. \\
\hline $\mathrm{X} 30$ & Terjadi Kerusuhan. \\
\hline
\end{tabular}

(Sumber: Hasil Olahan, 2020) 


\section{Analisis data}

Setelah data yang diterima dari responden telah dikumpulkan, maka data yang bersifat mentah tersebut perlu diolah agar menjadi matang. Data tersebut akan diolah menggunakan program SPSS. Pengolahan data akan melalui metode uji validitas dan uji reliabilitas untuk mendapatkan apakah data tersebut valid dan konkrit atau tidak. Selanjutnya, akan dilakukan analisis uji asumsi klasik dengan uji normalitas, lalu akan dilakukan analisis Relative Importance Index (RII).

\section{Uji validitas}

Uji validitas dilakukan untuk mengecek suatu keabsahan suatu instrumen pada kuesioner. Uji validitas yang akan digunakan adalah uji pearson product momen. Secara umum taraf signifikan yang digunakan adalah 0,05 atau signifikansi 5\%. Dengan bantuan program SPSS versi 24 untuk setiap variabel dengan kriteria sebagai berikut:

1. Jika nilai $\mathrm{r}$ hitung $\geq \mathrm{r}$ tabel, dapat dinyatakan instrumen penelitian berkorelasi signifikan terhadap skor total atau dapat dikatakan valid.

2. Jika nilai $r$ hitung $<\mathrm{r}$ tabel, dapat dinyatakan instrumen penelitian tidak berkorelasi signifikan terhadap skor total atau dapat dikatakan tidak valid.

\section{Uji reliabilitas}

Uji reliabilitas dilaksanakan untuk mengukur tingkat konsistensi responden dalam jawaban hal-hal yang berkaitan dengan pernyataan dalam kuesioner. Untuk menunjukan bahwa kuesioner ini cukup konsisten maka digunakan perhitungan nilai Alpha Cronbach. Uji Alpha Cronbach dilakukan untuk instrument yang dapat berupa angket, esai, maupun kuesioner. Instrumen dapat dikatakan reliabel jika koefisien Alpha Cronbach lebih dari 0,7.

\section{Uji normalitas}

Tujuan uji asumsi klasik adalah untuk mengetahui bahwa persamaan regresi memiliki ketepatan dan konsisten. Uji normalitas merupakan bagian dari uji asumsi klasik, uji normalitas bertujuan untuk melihat model regresi variabel dependen dan independen mempunyai kontribusi atau tidak. Salah satu metode pengerjaan uji normalitas adalah dengan Shapiro Wilk Test. Dasar pengambilan keputusan jika nilai signifikansi > 0,05 maka residual berdistribusi normal.

\section{Relative Importance Index (RII)}

Relative Importance Index (RII) merupakan suatu analisis yang dilakukan untuk pengolahan data mentah dari kuesioner untuk mengetahui ranking atau urutan kepentingan faktor tersebut. RII mempunyai persamaan sebagai berikut:

$$
R I I=\frac{5 n}{\underline{5}} \underline{+4 n} \underline{4} \underline{+3 n} \underline{3} \underline{\underline{3}}+2 n \underline{\underline{2}} \underline{ \pm 1} \underline{n} \underline{1}
$$

dengan $n_{5}=$ jumlah jawaban untuk skala $5, n_{4}=$ jumlah jawaban untuk skala $4, n_{3}=$ jumlah jawaban untuk skala 3, 2 = jumlah jawaban untuk skala 2, $1=$ jumlah jawaban untuk skala $1, \mathrm{~A}=$ skala terbesar, $\mathrm{N}=$ jumlah responden.

\section{HASIL DAN PEMBAHASAN}

Pada penelitian ini dilakukan pengumpulan data primer dengan menggunakan metode penyebaran kuesioner dan wawancara terhadap responden. Studi kasus penelitian terdapat pada proyek konstruksi gedung bertingkat di daerah DKI Jakarta.

Kuesioner telah disebarkan sebanyak 36 kuesioner kepada responden terkait dan didapatkan kuesioner yang kembali sebanyak 30 kuesioner dengan tingkat kembali (response rate) sebesar 83,33\% dan kuesioner yang tidak kembali sebanyak 10 kuesioner dengan presentase sebesar 16,67\%. Penyebaran kuesioner tersebut dilakukan selama bulan Maret - April 2020.

\section{Analisis dan pembahasan}

Pada bagian ini akan dilakukan analisis data dari hasil data responden yang telah dikumpulkan. Akan dilakukan beberapa pengujian instrument berupa: uji validitas, uji realibilitas, uji normalitas, dan analisis Relative Important Index (RII). Berbagai pengujian dilakukan agar didapatkan data yang valid dan konsisten dari data mentah yang terdapat pada kuesioner. Pengujian instrument tersebut akan menggunakan software IBM SPSS Statistic vers. 26. 


\section{Uji validitas}

Uji validitas ini dilakukan untuk mengetahui apakah data kuesioner yang diterima valid atau tidak. Jika instrument sudah valid, maka data dari kuesioner tersebut dapat digunakan. Pengujian validitas dilakukan kepada 30 sampel data yang diperoleh. Pengujian validitas dilakukan menggunakan bantuan software IBM SPSS Statistic vers. 26.

Langkah pertama yang dilakukan dalam uji validitas adalah mencari nilai r-tabel dengan nilai signifikansi sebesar 5\% dan jumlah responden 30 orang maka dapat dilihat pada tabel 3 berikut nilai r-tabel yang digunakan ialah 0,361 .

Tabel 3. Nilai R tabel

\begin{tabular}{cccccc}
\hline \multirow{2}{*}{$\mathbf{N}$} & \multicolumn{2}{c}{ Taraf Signifikan } & \multirow{2}{*}{ Taraf Signifikan } \\
\cline { 2 - 3 } \cline { 5 - 6 } & $\mathbf{5 \%}$ & $\mathbf{1 \%}$ & & $\mathbf{5 \%}$ & $\mathbf{1 \%}$ \\
\hline $\mathbf{2 1}$ & 0,433 & 0,549 & $\mathbf{2 6}$ & 0,388 & 0,496 \\
$\mathbf{2 2}$ & 0,423 & 0,537 & $\mathbf{2 7}$ & 0,381 & 0,487 \\
$\mathbf{2 3}$ & 0,413 & 0,526 & $\mathbf{2 8}$ & 0,374 & 0,478 \\
$\mathbf{2 4}$ & 0,404 & 0,515 & $\mathbf{2 9}$ & 0,367 & 0,47 \\
$\mathbf{2 5}$ & 0,396 & 0,505 & $\mathbf{3 0}$ & 0,361 & 0,463 \\
Sumber: Sugiono, 1999) & & &
\end{tabular}

Setelah dilakukan pengolahan data dengan memasukan 30 variabel independen kedalam software IBM SPSS Statistic vers. 26. Didapatkan nilai r-hitung atau total correlation dapat dilihat pada tabel 4.

Tabel 4. Hasil uji validitas

\begin{tabular}{ccccc}
\hline Simbol & Total Correlation & & R-Tabel & Keterangan \\
\hline X1 & 0,427 & $>$ & 0,361 & Valid \\
X2 & 0,457 & $>$ & 0,361 & Valid \\
X3 & 0,557 & $>$ & 0,361 & Valid \\
X4 & 0,430 & $>$ & 0,361 & Valid \\
X5 & 0,563 & $>$ & 0,361 & Valid \\
X6 & 0,462 & $>$ & 0,361 & Valid \\
X7 & 0,474 & $>$ & 0,361 & Valid \\
X8 & 0,462 & $>$ & 0,361 & Valid \\
X9 & 0,414 & $>$ & 0,361 & Valid \\
X10 & 0,521 & $>$ & 0,361 & Valid \\
X11 & 0,292 & $<$ & 0,361 & Tidak Valid \\
X12 & 0,415 & $>$ & 0,361 & Valid \\
X13 & 0,532 & $>$ & 0,361 & Valid \\
X14 & 0,514 & $>$ & 0,361 & Valid \\
X15 & 0,635 & $>$ & 0,361 & Valid \\
X16 & 0,445 & $>$ & 0,361 & Valid \\
X17 & 0,512 & $>$ & 0,361 & Valid \\
X18 & 0,409 & $>$ & 0,361 & Valid \\
X19 & 0,273 & $<$ & 0,361 & Tidak Valid \\
X20 & 0,549 & $>$ & 0,361 & Valid \\
X21 & 0,602 & $>$ & 0,361 & Valid \\
X22 & 0,639 & $>$ & 0,361 & Valid \\
X23 & 0,589 & $>$ & 0,361 & Valid \\
X24 & 0,463 & $>$ & 0,361 & Valid \\
X25 & 0,554 & $>$ & 0,361 & Valid \\
X26 & 0,416 & $>$ & 0,361 & Valid \\
X27 & 0,603 & $>$ & 0,361 & Valid \\
X28 & 0,293 & $<$ & 0,361 & Tidak Valid \\
X29 & 0,335 & $<$ & 0,361 & Tidak Valid \\
X30 & 0,556 & $>$ & 0,361 & Valid \\
\hline (S4 & &
\end{tabular}

(Sumber: Hasil Olahan, 2020) 
Salah satu syarat untuk mendapatkan variabel yang valid ialah variabel tersebut memiki nilai $\mathrm{r}$-hitung atau total correlation yang lebih besar dari nilai r-tabel. Dari hasil yang didapatkan, dapat disimpulkan bahwa dari 30 variabel, terdapat 4 variabel yang tidak valid dikarenakan memiliki nilai r-hitung yang lebih kecil daripada r-tabel.

\section{Uji reliabilitas}

Pengujian reliabilitas akan dilakukan untuk mengetahui tingkat konsistensi responden dalam menjawab kuesioner. Uji reliabilitas akan menggunakan bantuan software IBM SPSS Statistic vers. 26 untuk mengukur nilai Alpha Cronbach. Tingkat reliabilitas berdaskan nilai Alpha Cronbach dapat dilihat pada tabel 5.

Tabel 5. Tingkat reliabilitas

\begin{tabular}{cc}
\hline Nilai Alpha Cronbach & Keterangan \\
\hline$<0,5$ & Tidak diterima \\
$0,5 \sim 0,6$ & Reliabilitas kurang \\
$0,6 \sim 0,7$ & Masalah pada reliabilitas \\
$0,7 \sim 0,8$ & Reliabilitas diterima \\
$0,8 \sim 0,9$ & Reliabilitas baik \\
$0,9 \sim 1,0$ & Istimewa \\
\hline
\end{tabular}

(Sumber: Hassan, 2016)

Hasil pengolahan data dengan software IBM SPSS Statistic vers. 26 dapat dilihat pada tabel 6.

Tabel 6. Hasil nilai Alpha Cronbach uji reliabilitas

$\frac{\overline{\text { Nilai Alpha Cronbach }}}{0,887} \frac{\text { Nof items }}{26}$

(Sumber: Hasil Olahan,2020)

Dari hasil pengolahan didapatkan nilai Alpha Cronbach sebesar 0,889 dimana berada diantara 0,80 0,90 dan dapat disimpulkan bahwa data variabel tersebut memiliki reliabilitas yang baik dan memiliki data yang konsisten.

\section{Uji normalitas}

Uji normalitas dilakukan untuk mengetahui apakah residual pada penelitian ini sudah bersifat normal. Pada penelitian ini akan menggunakan uji normalitas dengan metode Shapiro Wilk Test. Model regresi yang dicari ialah model regresi yang memiliki residual berdistribusi normal dimana memiliki nilai signifikansi lebih besar dari 0.05. Dari hasil pengolahan data dengan software IBM SPSS Statistic vers. 26, didapatkan hasil nilai Shapiro Wilk seperti pada tabel 7 .

Tabel 7. Hasil uji normalitas Shapiro Wilk

\begin{tabular}{ccc}
\hline & Shapiro Wilk & Sig. \\
\hline Unstandardized Residual & 30 & 0,917 \\
\hline (Sumber: Hasil Olahan,2020) &
\end{tabular}

Berdasarkan hasil pengujian didapatkan nilai shapiro wilk sebesar 0,917>0,05 maka dapat disimpulkan bahwa model regresi pada penelitian ini memiliki residual yang berdistribusi normal.

\section{Relative Importance Index}

Dari variabel yang telah melewati proses validasi, variabel-varibael yang telah valid dan konsisten akan dianalisa untuk melihat nilai $R I I$. Nilai $R I I$ ini yang dapat menentukan faktor apa yang paling memengaruhi keterlambatan pada pekerjaan basement gedung bertingkat. Menurut (Akadiri, 2011), terdapat lima tingkat kepentingan yang didapatkan dari nilai RII. Tingkat kepentingan tersebut dapat dilihat pada tabel 8.

Tabel 8. Tingkat kepentingan nilai $R I I$

\begin{tabular}{ccc}
\hline Nilai $\boldsymbol{R I I}$ & & Tingkat Kepentingan \\
\cline { 1 - 1 } $0,8 \sim 1,0$ & & Tinggi $(\mathrm{T})$ \\
$0,6 \sim 0,8$ & & Tinggi-Sedang $(\mathrm{T}-\mathrm{S})$ \\
$0,4 \sim 0,6$ & & Sedang $(\mathrm{S})$ \\
$0,2 \sim 0,4$ & & Sedang-Rendah $(\mathrm{S}-\mathrm{R})$ \\
$0,0 \sim 0,2$ & & Rendah $(\mathrm{R})$ \\
\hline
\end{tabular}

(Sumber: Akadiri, 2011) 
Langkah awal yang perlu dilakukan adalah dengan menyusun tabel frekuensi dari jawaban responden untuk tiap variabel, setelah itu akan dilakukan perhitungan RII tiap variabel. Berikut pada table 9 merupakan nilai $R I I$ dan tingkat kepentingan tiap variabel.

Tabel 9. Nilai RII setiap variabel

\begin{tabular}{|c|c|c|}
\hline Variabel & Nilai $R I I$ & Kepentingan \\
\hline \multicolumn{3}{|c|}{ Faktor Metode Pelaksanaan } \\
\hline $\mathrm{X} 1$ & 0,593 & $\mathrm{~S}$ \\
\hline $\mathrm{X} 2$ & 0,633 & $\mathrm{~T}-\mathrm{S}$ \\
\hline $\mathrm{X} 3$ & 0,78 & $\mathrm{~T}-\mathrm{S}$ \\
\hline \multicolumn{3}{|c|}{ Faktor Material } \\
\hline $\mathrm{X} 4$ & 0,773 & $\mathrm{~T}-\mathrm{S}$ \\
\hline X5 & 0,62 & $\mathrm{~T}-\mathrm{S}$ \\
\hline X6 & 0,553 & S \\
\hline $\mathrm{X} 7$ & 0,573 & $\mathrm{~S}$ \\
\hline $\mathrm{X} 8$ & 0,647 & $\mathrm{~T}-\mathrm{S}$ \\
\hline \multicolumn{3}{|c|}{ Faktor Peralatan } \\
\hline $\mathrm{X} 9$ & 0,613 & $\mathrm{~T}-\mathrm{S}$ \\
\hline $\mathrm{X} 10$ & 0,607 & $\mathrm{~T}-\mathrm{S}$ \\
\hline \multicolumn{3}{|c|}{ Faktor Tenaga Kerja } \\
\hline X12 & 0,813 & $\mathrm{~T}$ \\
\hline $\mathrm{X} 13$ & 0,633 & $\mathrm{~T}-\mathrm{S}$ \\
\hline $\mathrm{X} 14$ & 0,693 & $\mathrm{~T}-\mathrm{S}$ \\
\hline $\mathrm{X} 15$ & 0,66 & $\mathrm{~T}-\mathrm{S}$ \\
\hline X16 & 0,64 & $\mathrm{~T}-\mathrm{S}$ \\
\hline \multicolumn{3}{|c|}{ Faktor Manajerial } \\
\hline $\mathrm{X} 17$ & 0,693 & $\mathrm{~T}-\mathrm{S}$ \\
\hline $\mathrm{X} 18$ & 0,853 & $\mathrm{~T}$ \\
\hline $\mathrm{X} 20$ & 0,74 & $\mathrm{~T}-\mathrm{S}$ \\
\hline \multicolumn{3}{|c|}{ Faktor Terkait Informasi } \\
\hline $\mathrm{X} 21$ & 0,727 & $\mathrm{~T}-\mathrm{S}$ \\
\hline $\mathrm{X} 22$ & 0,7 & $\mathrm{~T}-\mathrm{S}$ \\
\hline $\mathrm{X} 23$ & 0,727 & $\mathrm{~T}-\mathrm{S}$ \\
\hline \multicolumn{3}{|c|}{ Faktor Karakteristik dan Lingkungan Proyek } \\
\hline $\mathrm{X} 24$ & 0.74 & $\mathrm{~T}-\mathrm{S}$ \\
\hline $\mathrm{X} 25$ & 0.713 & $\mathrm{~T}-\mathrm{S}$ \\
\hline $\mathrm{X} 26$ & 0.773 & $\mathrm{~T}-\mathrm{S}$ \\
\hline $\mathrm{X} 27$ & 0.773 & $\mathrm{~T}-\mathrm{S}$ \\
\hline \multicolumn{3}{|c|}{ Faktor Lainnya } \\
\hline $\mathrm{X} 30$ & 0,653 & $\mathrm{~T}-\mathrm{S}$ \\
\hline
\end{tabular}

(Sumber: Hasil Olahan, 2020)

Dari nilai RII diatas didapatkan ranking dari faktor-faktor yang paling berpengaruh terhadap keterlambatan pekerjaan basement gedung bertingkat yang disajikan pada tabel 10 .

Tabel 10. Ranking faktor yang memengaruhi keterlambatan basement

\begin{tabular}{lccc}
\hline \multicolumn{1}{c}{$\begin{array}{c}\text { Faktor-Faktor Keterlambatan pada } \\
\text { Pekerjaan Basement }\end{array}$} & Kelompok Faktor & RII & Rank \\
\hline Perubahan perintah kerja dan variasi dari owner & Manajerial & 0,853 & 1 \\
Produktivitas pekerja lapangan yang rendah & Tenaga Kerja & 0,813 & 2 \\
Terjadi kebocoran pada Dinding Penahan Tanah (DPT). & Metode Pelaksanaan & 0,78 & 3 \\
Pengaturan tata letak penyimpanan tulangan yang berulang-ulang & Karakteristik dan & 0,773 & 4 \\
akibat lahan yang terlalu sempit. & Lingkungan Proyek & 0,773 & 4 \\
Pengiriman material yang terlambat & Material & & \\
\hline
\end{tabular}

(Sumber: Hasil Olahan, 2020)

Dari tabel diatas diketahui 5 faktor yang paling mempengaruhi keterlambatan pekerjaan basement gedung bertingkat semi top-down, pada posisi pertama merupakan perubahan perintah kerja dan variasi dari owner dengan nilai $R I I$ sebesar 0,853 , kedua merupakan produktivitas pekerja lapangan yang rendah dengan nilai $R I I$ sebesar 
0,813, posisi ketiga merupakan terjadi kebocoran pada dinding penahan tanah dengan nilai $R I I$ sebesar 0,78 , untuk posisi keempat terdapat dua factor dengan nilai $R I I$ yang sama yaitu pengaturan tata letak penyimpanan tulangan yang berulang-ulang akibat lahan yang terlalu sempit dan pengiriman material yang terlambat dengan nilai $R I I$ sebesar 0,773 .

\section{KESIMPULAN DAN SARAN}

\section{Kesimpulan}

Kesimpulan yang didapat berdasarkan hasil analisis data pada penelitian faktor-faktor penyebab keterlambatan waktu pada pekerjaan basement gedung bertingkat semi top-down adalah sebagai berikut:

1. Didapatkan 5 faktor-faktor utama yang menyebabkan keterlambatan pada pekerjaan basement semi topdown dengan ranking sebagai berikut:

a. Perubahan perintah kerja dan variasi dari owner.

b. Produktivitas pekerja lapangan yang rendah.

c. Terjadi kebocoran pada Dinding Penahan Tanah (DPT).

d. Pengaturan tata letak penyimpanan tulangan yang berulang-ulang akibat lahan yang terlalu sempit.

e. Pengiriman material yang terlambat.

2. Faktor yang paling berpengaruh pada keterlambatan pekerjaan basement semi top-down adalah Perubahan perintah kerja dan variasi dari owne, dan kelompok faktor yang paling mempengaruhi keterlambatan ialah faktor manajerial.

\section{Saran}

Dari faktor-faktor penyebab keterlambatan waktu pada pekerjaan basement gedung bertingkat semi top-down, beberapa saran untuk kedepannya adalah sebagai berikut:

1. Berdasarkan hasil penelitian keterlambatan basement semi top-down, Para pelaku jasa kontruksi harus menjaga komunikasi dengan baik agar menghindari terjadinya kesalahpahaman dan menghindari perubahan kerja yang berubah-ubah yang dapat menyebabkan keterlambatan.

2. Kontraktor pelaksana harus memerhatikan sistem manajerial dengan baik agar dapat menghindari keterlambatan pada pekerjaan basement.

3. Diperlukan pengawasan yang lebih ketat dari pihak kontraktor dan owner agar bisa menghindari terjadinya keterlambatan yang berulang-ulang.

4. Dikarenakan pada penelitian ini hanya melihat sudut pandang dari kontraktor, untuk penelitian selanjutnya dapat memperluas penelitian ini dengan melihat faktor keterlambatan dari sudut pandang owner dan konsultan.

\section{DAFTAR PUSTAKA}

Alifen, R. S., R. S. Setiawan and A. Sunarto. "Analisa "What If" Sebagai Metode Antisipasi Keterlambatan Durasi Proyek." Dimensi Teknik Sipil vol. 2 no. 1, Maret (2000).

Kerzner, Harold. Project Management: A System Approach to Planning, Schedulling, and Controlling. Ohio: John Wiley \& Sons, Inc, 2003.

Kog, Yue Choong. "Construction Delays in Indonesia, Malaysia, Thailand, and Vietnam." Pract. Period. Struct. Des. Constr., 2019 (2019).

Lafiza, Ardy. Analisa Perbandingan Metode Top-Down dan Bottom-Up Pada Proyek Fave Hotel Ketintang Ditinjau dari Segi Biaya dan Waktu. Surabaya: Institut Teknologi Sepuluh Nopember, 2017.

Lo, Tommy Y., Ivan W.H. Fung and Karen C. Tung. "Construction Delays in Hong Kong Civil Engineering Projects." Journal of Construction Engineering and Management ASCE (2006).

Mistra. Struktur dan Konstruksi Bangunan Tinggi Sistem Top and Down. Jakarta: Griya Kreasi, 2012.

Praboyo, Budiman. "Keterlambatan Waktu Pelaksanaan Proyek: Klasifikasi dan Peringkat dari PenyebabPenyebabnya." Diskusi Teknik Sipil Volume 1 No 2 (1999).

Prawidiawati, Fitri. Analisa Perbandingan Metode Bottom-Up dan Metode Top-Down Pekerjaan Basement pada Gedung Parkir Apartemen Skyland City Education Park Bandung Dari Segi Biaya dan Waktu. Surabaya: Institut Teknologi Sepuluh Nopember, 2015. 
Rani, H.A. Manajemen Proyek Konstruksi. Yogyakarta: Deepublish, 2016.

Sari, Ninditya Mustika. Metode Pelaksanaan Pembangunan Proyek Apartemen One East Surabaya Dengan Metode Top-Down. Surabaya: Institut Teknologi Sepuluh Nopember, 2015.

Sugiono. Metodologi Penelitian Administrasi Edisi Kedua. Bandung: CV Alfa Beta, 1999.

Sugiyono. Metode Penelitian Pendidikan Pendekatan Kuantitatif, Kualitatif, dan R\&D. Bandung: Alfabeta, 2009.

Tafazzoli, Mohammadsoroush and Pramen Shrestha. "Factor Analysis of Construction Delays in the U.S. Construction Industry." International Conference on Sustainable Infrastructure (2017).

Tanubrata, M. Pelaksanaan Konstruksi Dengan Sistem Top Down. Bandung: Simposium Nasional RAPI XIV, 2015.

Teulah, Joel D.P., Jermias Tjakra and D.R.O. Walangitan. "Pernanan Konsultan Manajemen Konstruksi pada Tahap Pelaksanaan Proyek Pembangunan." Tekno Sipil / Volume 12 / No. 61 (2014).

Wirabakti, Deden Matri, Rahman Abdullah and Andi Maddeppungeng. "Studi Faktor-Faktor Penyebab Keterlambatan Proyek Konstruksi Bangunan Gedung." Journal Konstruksia / Vol.6 No. 1 / Desember (2014).

Wisudanto, Agus W. Faktor-Faktor Penyebab Keterlambatan Pada Proyek Konstruksi Gedung di Kediri. Surabaya: Institut $\quad$ Teknologi $\quad$ Sepuluh 2012. 
